\title{
Sal Forest: A Source of Wild Edible Mushrooms for Livelihood Support to Tribal People of Dindori District, Madhya Pradesh, India
}

\author{
R.K. Verma*, Vimal Pandro, S.N. Mishra, Diwyansh Raj and A.J.K. Asaiya
}

Forest Pathology Discipline, Forest Protection Division, Tropical Forest Research Institute, Jabalpur - 482 021, Madhya Pradesh, India

*Corresponding author

\section{A B S T R A C T}

\section{Keywords}

Central India,

Edible mushrooms,

Mushroom hunting,

Termite mounds

Article Info

Accepted:

07 December 2018

Available Online:

10 January 2019
Information on wild edible mushrooms was collected from sal forests of Dindori district, Madhya Pradesh by visiting different sites in forest areas. Rural folk/ tribal people were contacted and information was recorded by personal interviewing. Commonly collected mushrooms from sal were: Astraeus hygrometricus, Russula congoana, Termitimyces clypeatus, T. eurhizus, T. microcarpus and Termitomyces $\mathrm{sp}$.

\section{Introduction}

Edible mushrooms belong to genera Astraeus, Russula and Termitomyces are used in food by Baiga and Gond tribes of Dindori district, Madhya Pradesh. The gasteroid fungus Astraeus hygrometricus was reported as early as in 18th century as Geastrum (Persoon, 1801). Till date 10 species are known which include: Astraeus asiaticus, A. koreanus, A. morganii, A. odoratus, A. pteridis, $A$. sirindhorniae, A. smithii, A. telleriae and A. thailandicus. The genus has worldwide distribution especially in the sandy soils forests of Africa, Asia, Australia, Europe,
Mexico, North America and South America (Pavithra et al., 2015). A. hygrometricus is distributed in 11 Indian states of India including, Himachal Pradesh, Jharkhand, Karnataka, Kerala, Odisha, Punjab, Uttarakhand, Uttar Pradesh and West Bengal (Verma et al., 2017a). Eight species of gilled mushroom, Russula, namely $R$. congoana, $R$. crustosa, $R$. lepida, $R$. lutea, $R$. olivacea, $R$. parvovirescens, $R$. senecis and $R$. virescens were reported to be edible (Verma et al., 2018). Edible mushrooms, A. hygrometricus, $R$. lepida, $T$, eurrhizus, $T$. heimii, $T$. microcarpus were reported to be collected from sal (Shorea robusta) forests by local 
people and Tibetan residents in Dehradun, Uttarakhand (Semwal et al., 2014). Twelve species of Russula including some edible species ( $R$. congoana) were reported from Kerala (Mohanan, 2014). Genus Termitomyces was established in 1942 (Heim, 1942) and its various species are reported to be edible for most people. These mushrooms grow on 'combs' which are formed from the termites' excreta, dominated by tough woody fragments (Makonde et al., 2013).

Edible species of Termitomyces include: T. albuminosus, T. clypeatus, T. globules, T. heimii, T. microcarpus, T. sagittiformis, $T$. striatus, etc. Termitomyces eurrhizus is a wild edible mushroom used by ethnic tribes of Nagaland (Bhaben et al., 2011) and it was also reported from a market of Midnapur, West Bengal (Purkayastha and Chandra, 1975). Eighteen edible Termitomyces species were reported from Western Ghats (Karun and Sridhar, 2017). Role of wild edible mushrooms collected from Shorea robusta forest ecosystem by the Santal in lateritic region of West Bengal was studied and inventoried (Pradhan et al., 2010; 2013a, b).

Information on collection and utilization of this mushroom were also available from Nepal and Japan (Christensen et al., 2008, Fangfuk et al., 2010).

Studies were conducted in dry deciduous forests of lateritic eastern parts of India on economic contribution of wild edible mushrooms of a forest fringe ethnic community (Manna and Roy, 2014) and its tribal relation to spatio-temporal variation were reported (Manna et al., 2014).

In the present study an estimate of edible mushrooms (Astraeus, Russula and Termitomyces) collected by local and tribal people from sal forest of Dindori district, Madhya Pradesh and their role in economy of rural folk is given.

\section{Materials and Methods}

\section{Study sites}

Dindori is a district of Madhya Pradesh state of central India it is situated on the eastern part of the state. The district is surrounded by Shahdol in the East, Mandla in the West, Umaria in the North and Bilaspur and Kawardha (Chhattisgarh) in the South. It is located at $22.95^{\circ} \mathrm{N} 81.08^{\circ} \mathrm{E}$ and an average elevation of 640 metres $(2,099$ feet $)$. The total area of the district is 7,470 sq. kms and is surrounded by herbal rich Maikal mountain ranges. It is divided into seven blocks namely Dindori, Shahpura, Mehandwani, Amarpur, Bajag, Karanjiya and Samnapur (http://www.dindori.mp.gov.in). About 64\% of the population belongs to tribal communities like Koel, Gond, Korwa, Baiga, and others. The timber trees of district are: sal, saj, amla, teak, tendu and tinsa. In addition of this, dhawda, bija, lencha, hardu and koha are common trees found throughout the district. Bamboo is also rarely available in the district. The sal trees are grown most luxuriantly in sandy soil, especially in Dindori and its neighboring districts. Specimens of edible mushrooms were collected from different places sal forests of Dindori district for microscopic study. Information on sale of mushrooms were collected from Bajag, Bhilania, Chada, Chandnalalpur, Chada road (near forest range office), Tarach, Chakrar, Gadasarai, Gorakhpur, Jhigri, Labeda, Karanjia, Nevsa (Amarkantak road) and Rusa of Dindori district in Madhya Pradesh (Fig. 1).

\section{Collection of mushroom}

Edible mushrooms were collected by local people during rainy seasons mainly from sal forests and its associate tree species during rainy season (July-Sep). The immature fruit bodies of Astraeus hygrometricus were collected from sal forests during early (June) 
to late monsoon (August) (Fig. 2). Mature open fruit bodies with wings are not edible (Fig. 3). Under sal trees careful observation were made to locate cracks on soil surface and with white matrix. The scratching of soil surface was done below the crack surface to locate the immature fruit bodies with the help of iron or wooden tools. The immature basidiomata were solitary or in cluster of 4-10, fully or partially buried $(0.5-1 \mathrm{~cm}$ deep) in soil and/ or sometimes visible along with pebbles of laterite soil as bone-white mycelial mass (Verma et al., 2017a). Termitomyces species are deeply rooted and arises from termite mounds. For collection of these mushrooms soil is deeply dug with the help of pointed wooden (preferably bamboo) or iron ram (Fig. $4,5)$. The dug out mushroom along with long stipes were collected, wrap in mahul patta (Bauhinia vahlii) or bound in bundles for sale. Fruit bodies of Russula species are easy to collect, the fruit bodies are plucked from the soil surface by hand.

\section{Collection of information on mushrooms}

Local markets were visited for collection of information on sale of mushrooms. Local village markets and road sides were also observed for sale of mushrooms. Information was collected from mushrooms sellers/ collectors. 10 local mushroom collectors/ sellers were contacted and information on collection of wild mushroom was collected (Table 4).

\section{Processing of specimens and microscopic study}

Some parts of collected samples were preserved in $70 \%$ alcohol just after collection for microscopic study. The fruit bodies of fungi were dried under the sun or in the wooden box lighted with $100 \mathrm{~W}$ electric bulb. Microscopic slides were prepared by using stain, mountant, clearing and softening chemicals. Slides were observed under advanced research microscope (Leica, Germany) using 5x,10x, 20x, 40x objectives and $10 \mathrm{x}$ and $15 \mathrm{x}$ eyepieces. Observations under phase contrast and dark field were also made whenever required. Photomicrography was done with the help of a digital camera (make, Leica) attached to the advanced microscope.

\section{Identification of mushrooms}

Identification of fungi has been done with the help of published literature, monographs, books, keys, etc. (Ahmad, 1950; Christensen et al., 2008; Dring, 1964; Fangfuk et al., 2010; Hembrom et al., 2014; Karun and Sridhar, 2014; Mohanan, 2011; Pavithra et al., 2015; Phillips, 2006; Pradhan et al., 2013a, b; Pyasi et al., 2011; Semwal et al., 2014; Surcek, 1998).

\section{Results and Discussion}

Information on wild edible mushrooms occurring in sal forests of Dindori district, Madhya Pradesh were conducted and mushroom collected by local people for their self use and for sale in local markets were collected. Mushroom is being frequently collected from sal forest belongs to 3 genera namely; Astraeus (Fig. 2), Russula (6) and Termitomyces (Figs. 7-10), these mushrooms were collected on large scale (Table 1). Besides these few species of Amanita and Pleurotus were also collected on small scale. Information on sale of these mushrooms in local markets and road side were also collected from different areas including, Bajag, Chada, Chakrar, Chandnalalpur, Jhigri, Karanjia, Labeda, Nevsasal and Rusa villages (Table 2, 3). These places were personally visited and information was collected. 10 persons were interviewed and data on collection and marketing of mushroom was collected. 
The local people collect immature fruit bodies of A. hygrometricus (also known as 'Sehula' in Uttar Pradesh meaning mushroom from sal forest and 'Puttu' in Madhya Pradesh) during June-September and the highest yield obtained during July-August. Local people identify troops of A. hygrometricus by scratching the surface of soil and looking for white matrix. Wherever white matrix seen on the surface or subsurface, it is a perfect indication that troops of immature fruit bodies prevail in its surroundings. Local family member harvests tender A. hygrometricus during rainy season and female members were likely to sell in local markets (Fig. 12-13). Probability of finding mushrooms is likely to be more in open and buffer zones as compared to typical forest locations. Termitomyces species were collected by all family including children (especially female members) (Fig. 14). Harvested mushrooms are collected in bamboo baskets (Figs. 15-16). The harvested mushroom is cleaned with water to remove debris and hairy structures on the surface. The mushrooms are wrapped in mahul patta or make bundles (Fig. 17-18) and sold on the road side, if buyers are available (Fig. 19). Collected tender mushroom reaches to the local markets or road sides on the same day (Figs. 20-23). Sale of Termitomyces mushroom was also noticed along with vegetable of tree origin (Menhar) at Bajag in Dindori (Fig. 22). Usually cleaned mushrooms will be cooked and consumed on the same or subsequent day. In the present study data on collection of wild edible mushrooms by tribal people/ local inhabitants from sal forest of Dindori district, Madhya Pradesh was compiled from 9 places (Bajag, Chada, Chakrar, Chandnalalpur, Jhigri, Karanjia, Labeda, Nevsasal and Rusa) (Table 1-4). Earlier such study was conducted from forests in the aid of tribal people including women of Madhya Pradesh (Harsh et al., 1993; 1996). Such type of information was also available from Nagaland (Bhaben et al., 2011). Use of mushrooms as future vegetable was proposed (Harsh and Joshi, 2008). Besides edible fungi use of Ganoderma lucidum in folk medicine was also studies (Harsh et al., 1993). In a study Vrinda and Pradeep (2014) has listed 85 edible mushrooms from Kerala. The list also include many mushrooms collected from central India including, Agaricus bisporus, Boletellus ananas (Verma and Pandro, 2018a), Laccaria laccata, Lentinus sajor-caju, Macrocybe lobayensis (Verma et al., 2017b), Macrolepiota procera, Pleurotus eous, $P$. flabellatus, P. ostreatus, Russula adusta, $R$. congoana, Schizophyllum commune (Verma and Verma, 2017b), Strobilomyces floccopus, Termitomyces clypeatus, T. eurhizus, $T$. globules, T. heimii, T. microcarpus. Amanita hemibapha an edible mushroom was reported to be collected from Khasi Hills, Meghalaya; Thiruvananthapuram, Wayanad, Malappuram, Kerala; Rudraprayag, Jakholi, Pauri, Kanda; Dehradun and Uttarakhand (Berkeley, 1852; Vrinda et al., 2005; Pradeep and Vrinda, 2007, 2010; Mohanan, 2011; Semwal et al., 2014).

Table.1 List of wild edible mushrooms collected from sal forest and its associate tree species of Dindori district, Madhya Pradesh

\begin{tabular}{|l|l|l|}
\hline S.No. & Botanical name & Local name of mushroom \\
\hline 1. & Astraeus hygrometricus & Puttu, Rugra \\
\hline 2. & Russula congoana & Sarai Pihari \\
\hline 3. & Termitimyces clypeatus & Chirko Pihari \\
\hline 4. & Termitomyces eurhizus & Bhondo Pihari \\
\hline 5. & Termitomyces sp. & Raj Bhondo Pihari (big size) \\
\hline 6. & Termitomyces microcarpus & Bhat Pihari \\
\hline
\end{tabular}


Table.2 Market survey and collection of information on edible mushrooms collected from sal forests of Dindori district, Madhaya Pradesh

\begin{tabular}{|c|c|c|c|c|c|c|}
\hline S.N. & $\begin{array}{l}\text { Name of } \\
\text { mushroom }\end{array}$ & $\begin{array}{l}\text { Place of } \\
\text { collection }\end{array}$ & $\begin{array}{l}\text { Period of } \\
\text { collection }\end{array}$ & $\begin{array}{l}\text { Family } \\
\text { member } \\
\text { involved in } \\
\text { collection of } \\
\text { mushroom }\end{array}$ & $\begin{array}{l}\text { Estimated } \\
\text { quantity of } \\
\text { mushroom } \\
\text { collected/ day/ } \\
\text { family (kg) }\end{array}$ & $\begin{array}{l}\text { Market } \\
\text { price per } \\
\text { kg (Rs.) }\end{array}$ \\
\hline 1. & Termitomyces & $\begin{array}{l}\text { Bajag road, } \\
\text { Lalpur }\end{array}$ & July- Aug. & $2-3$ & $4-6$ & $250-350 /-$ \\
\hline 2. & Russula & Tarach, Bajag & July- Aug. & $1-2$ & $3-5$ & $60-150 /-$ \\
\hline 3. & Termitomyces & Tarach, Bajag & July- Aug. & $3-4$ & $2-5$ & $250-350 /-$ \\
\hline 4. & $\begin{array}{l}\text { Astraeus } \\
\text { hygrometricus }\end{array}$ & Chada & June-Aug & $4-5$ & $10-12$ & 60-100/- \\
\hline 5. & Russula & Chada & July-Aug & $3-4$ & $6-8$ & $60-150 /-$ \\
\hline 6. & $\begin{array}{l}\text { Astraeus } \\
\text { hygrometricus }\end{array}$ & Gadasarai & June-Aug & $3-4$ & $10-15$ & 60-100/- \\
\hline 7. & Termitomyces & Gadasarai & July-Aug & $2-3$ & $5-6$ & $200-350 /-$ \\
\hline 8. & $\begin{array}{l}\text { Astraeus } \\
\text { hygrometricus }\end{array}$ & $\begin{array}{l}\text { Nevsa, Purani } \\
\text { Dindori }\end{array}$ & June-July & $4-5$ & $6-7$ & 60-100/- \\
\hline 9. & $\begin{array}{l}\text { Astraeus } \\
\text { hygrometricus }\end{array}$ & $\begin{array}{l}\text { Chada road, } \\
\text { near Bajag }\end{array}$ & June-Aug & $2-3$ & $5-6$ & $60-100 /-$ \\
\hline 10. & $\begin{array}{l}\text { Termitomyces } \\
\text { sp. }\end{array}$ & $\begin{array}{l}\text { Bhilania, } \\
\text { Bajag }\end{array}$ & July-Aug & $3-4$ & $0.80-1.0$ & $320 /-$ \\
\hline 11. & $\begin{array}{l}\text { Termitomyces } \\
\text { sp. }\end{array}$ & $\begin{array}{l}\text { Chada road } \\
\text { Bajag }\end{array}$ & July-Aug & $4-5$ & $1.5-2.0$ & $250-350 /-$ \\
\hline 12. & $\begin{array}{l}\text { Termitomyces } \\
\text { sp. }\end{array}$ & $\begin{array}{l}\text { Ladbena, } \\
\text { Chada Road }\end{array}$ & July-Aug & $3-4$ & $2-3$ & 200/- \\
\hline 13. & $\begin{array}{l}\text { Termitomyces } \\
\text { sp. }\end{array}$ & $\begin{array}{l}\text { Chada Road, } \\
\text { in sal forest }\end{array}$ & July-Aug & $3-5$ & $2-3$ & 200-300/- \\
\hline 14. & $\begin{array}{l}\text { Termitomyces } \\
\text { sp. }\end{array}$ & $\begin{array}{l}\text { Amarkantak } \\
\text { Road, Rusa, } \\
\text { Karanjiaya }\end{array}$ & July-Aug & $2-3$ & $2-3$ & $200-350 /-$ \\
\hline 15. & $\begin{array}{l}\text { Astraeus } \\
\text { hygrometricus }\end{array}$ & $\begin{array}{l}\text { Amarkantak } \\
\text { Road, } \\
\text { Gorakhpur, } \\
\text { Karanjiya }\end{array}$ & June-Aug & $2-4$ & $8-10$ & $80-100 /-$ \\
\hline 16. & $\begin{array}{l}\text { Termitomyces } \\
\text { heimii }\end{array}$ & $\begin{array}{l}\text { Amarkantak } \\
\text { Road, } \\
\text { Gadasarai }\end{array}$ & July-Aug & $1-2$ & $2-2.5$ & 280-300/- \\
\hline
\end{tabular}


Table.3 Name of persons who provide information on mushroom along with address

\begin{tabular}{|l|l|l|}
\hline S.N. & Name of person & Address \\
\hline 1. & Arjun Singh Saler & Chada road, near Forest range Office, Bajag, \\
\hline 2. & Budhvaria Bai. & Gram - Chada, Bajag, Dindori, Madhya Pradesh \\
\hline 3. & Dhansingh Maravi & Gram - Chakrar, Karanjia block, Dindori, Madhya Pradesh \\
\hline 4. & Govindsingh Dhurve & Gram - Chada, Bajag, Dindori, Madhya Pradesh \\
\hline 5. & Indravati & Gram - Chada, Bajag, Dindori, Madhya Pradesh \\
\hline 6. & Laliyabai and Kalavati & Gram - Chandnalalpur, Jhigri, Rusa, Dindori, Madhya Pradesh \\
\hline 7. & Raisingh & Gram - Chada, Bajag, Dindori, Madhya Pradesh \\
\hline 8. & Raju Rathour Saler & Nevsa, Amarkantak Road, Purani Dindori, Madhya Pradesh \\
\hline 9. & Ramkalibai and & Gram - Jhigri, Rusa, Dindori, Madhya Pradesh \\
\hline 10. & Shemvati Paraste & \\
\hline & Shobhit Singh Aarmo & Gram - Labeda, Bajag, Dindori, Madhya Pradesh \\
\hline
\end{tabular}

Fig.1 Study area (study spots shown with black dots)
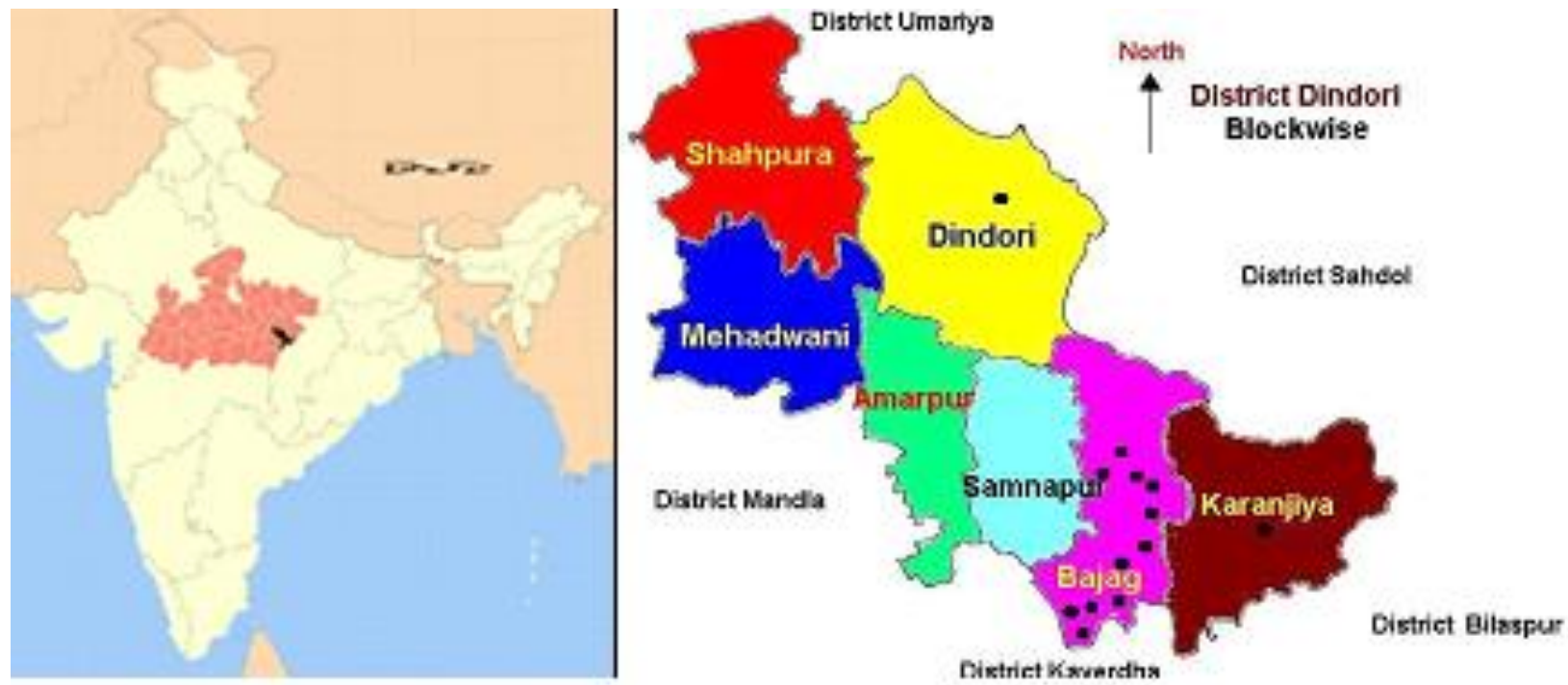

Fig.2\&3 Astraeus hygrometricus: 2. Hypogenous and edible fruit bodies, 3. epigeous and open fruit bodies in their natural area (not edible)

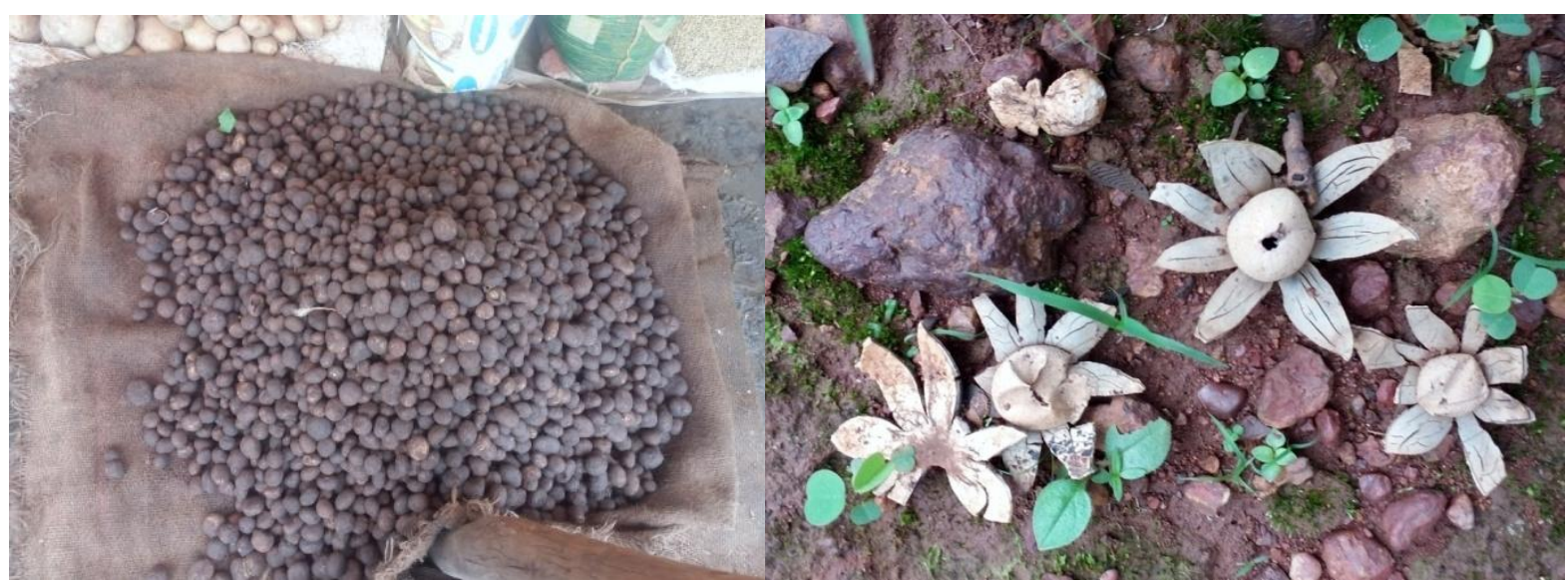


Fig.4\&5 Termitomyces: collection of mushroom by digging soil in sal forest

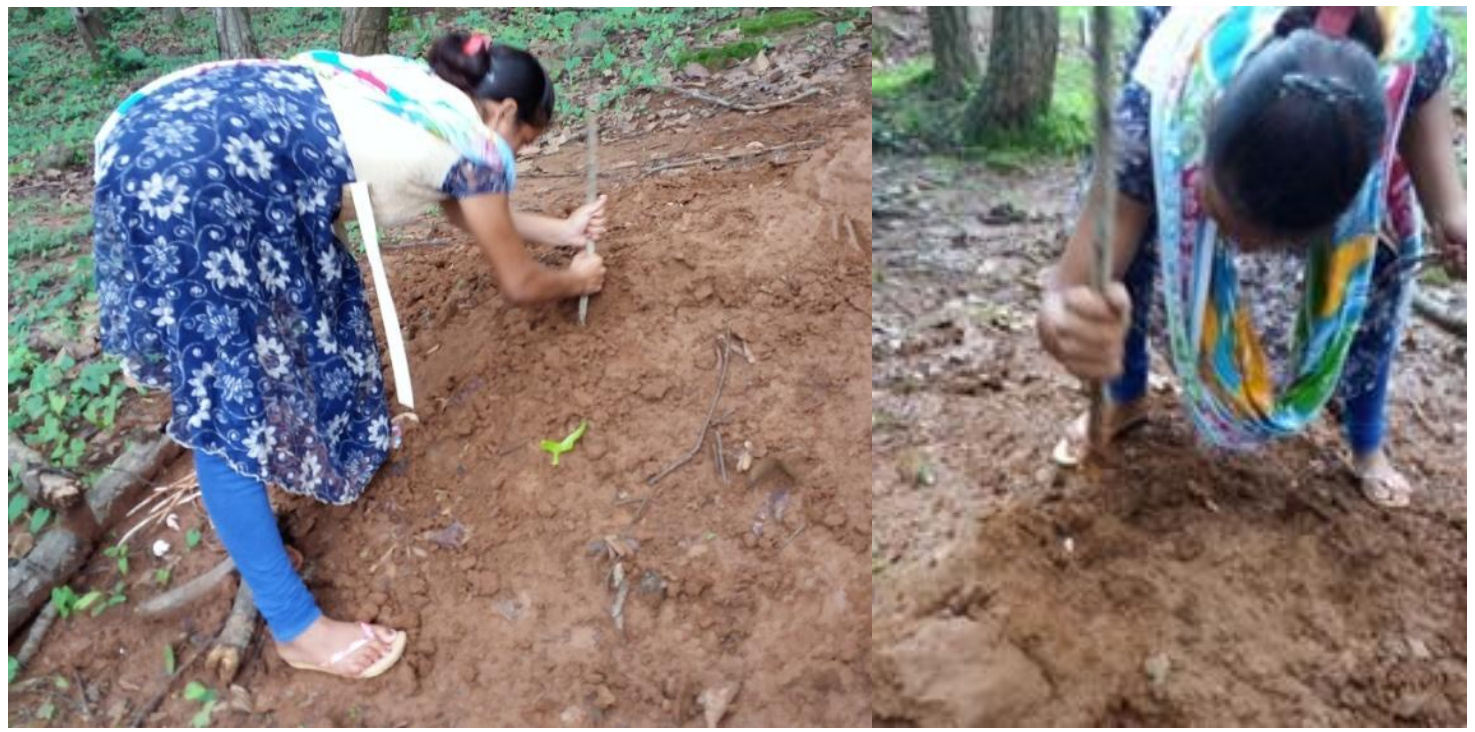

Fig.6 Russula congoana, fruit body growing in sal forest

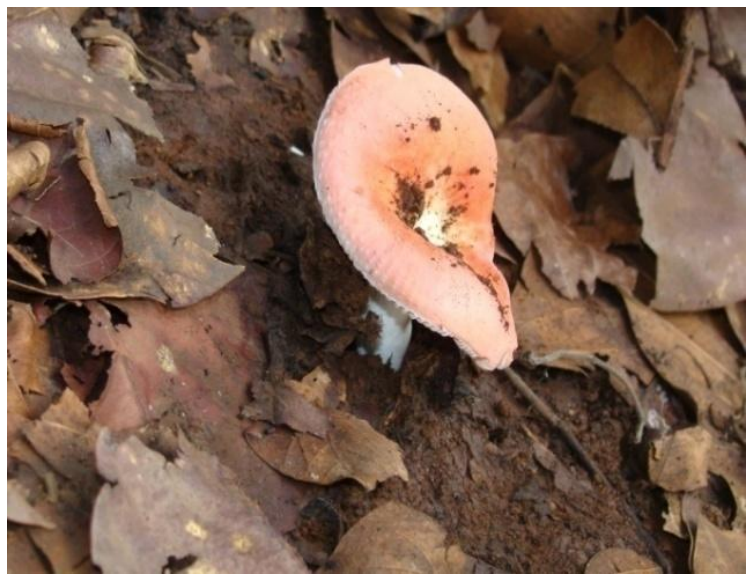

Fig.7,8\&9 Termitomyces: Young fruit body from termite mount Figures 6: Mushrooms collected from sal forest by local and tribal people for their consumption and sale in local market

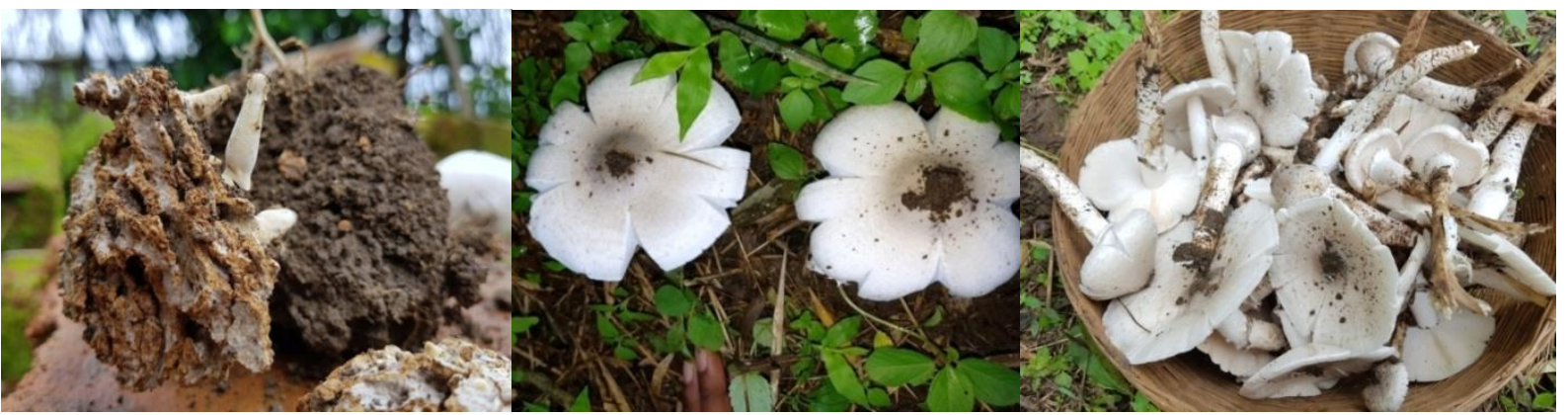


Fig.10\&11 Astraeus hygrometricus: collected from sal forest and sale in local market along with other vegetables at Dindori, Madhya Pradesh

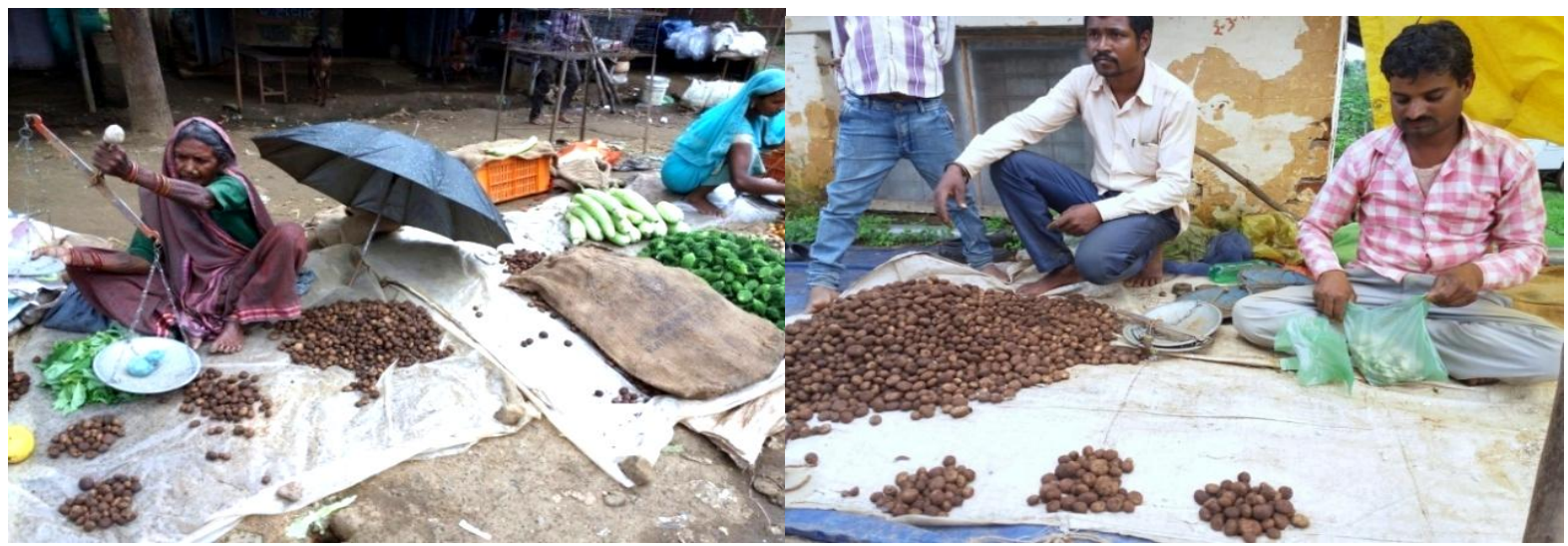

Fig.12\&13 Astraeus hygrometricus: 11 a Tribal family with collected mushroom, man showing edibility of mushroom by eating it raw and 12 selling of mushrooms (Astraeus hygrometricus and Termitomyces) in local market collected from sal forest of Dindori, Madhya Pradesh by local women

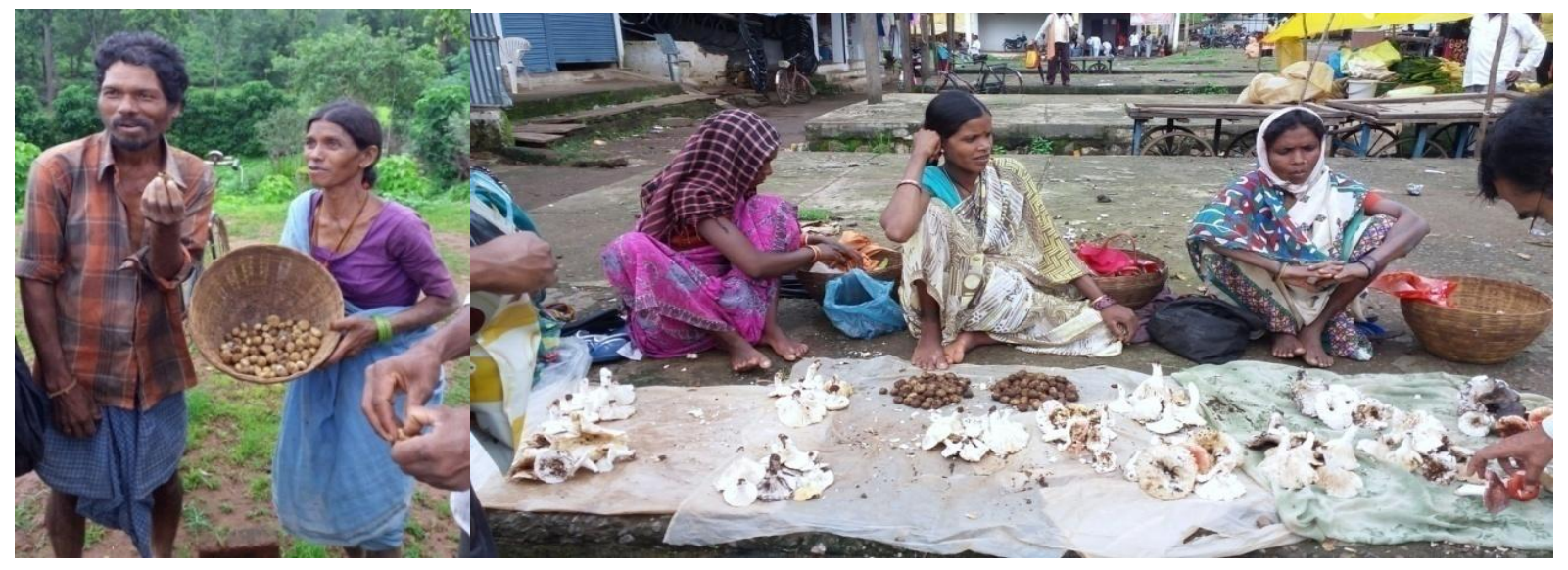

Fig.14 Termitomyces: tribal family members including children on trip of mushroom hunting from sal forest, Dindori, Madhya Pradesh

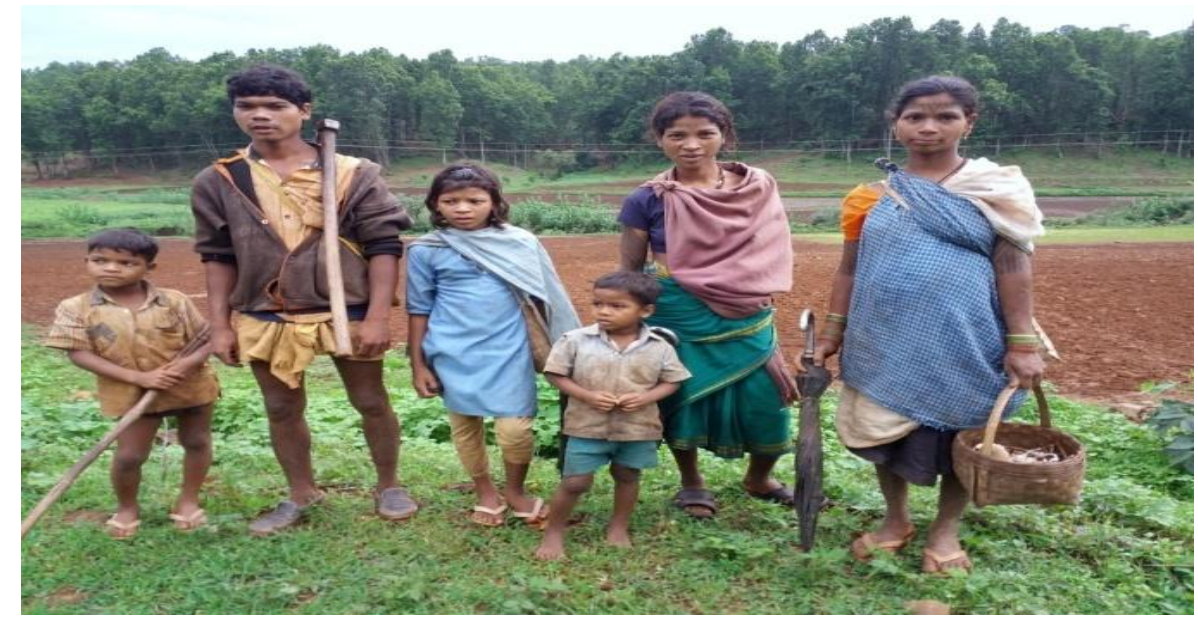


Fig.15\&16 Termitomyces: 14, a tribal lady along with collected mushroom from sal forest, Dindori, Madhya Pradesh, 15, mushroom kept in bamboo basket for carriage

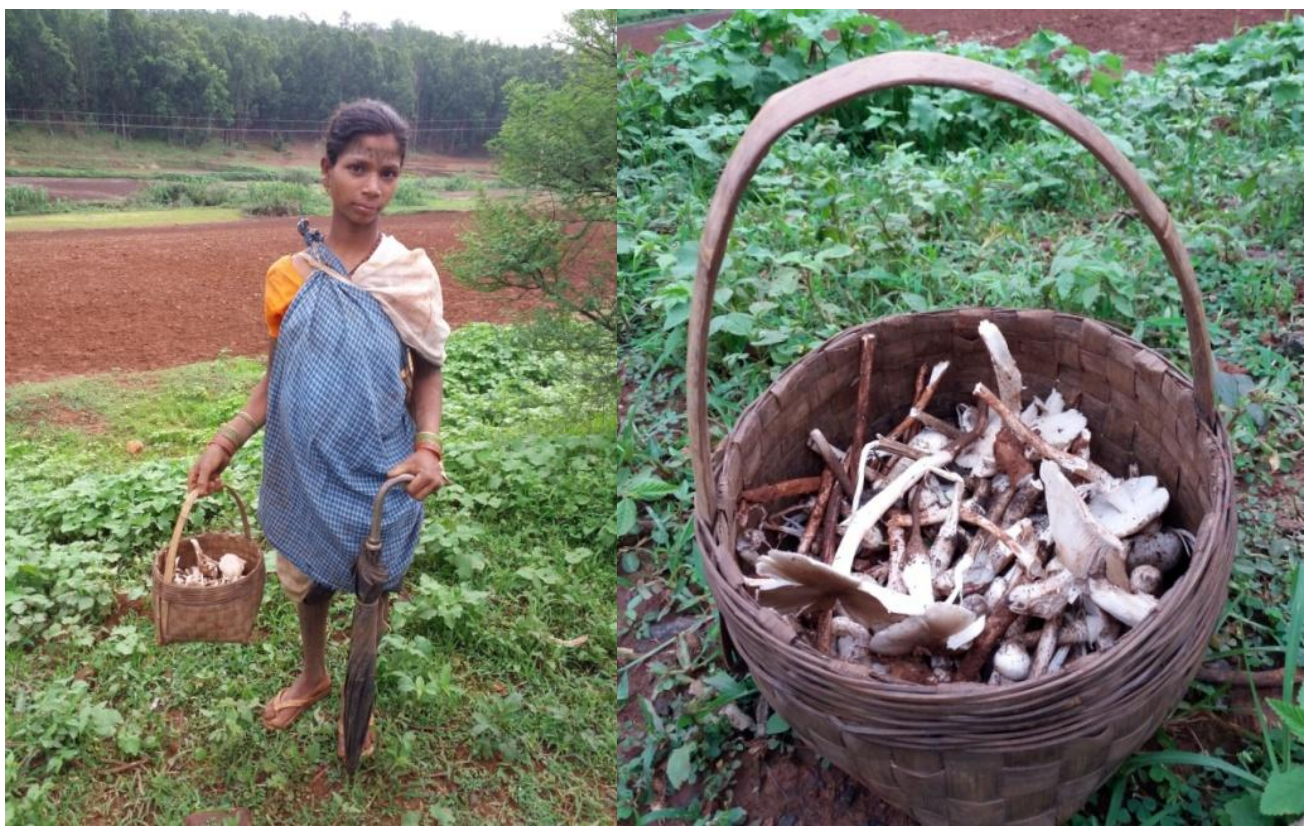

Fig.17,18\&19 Termitomyces: selling of mushroom at road side at Dindori-Chada road, Madhya Pradesh

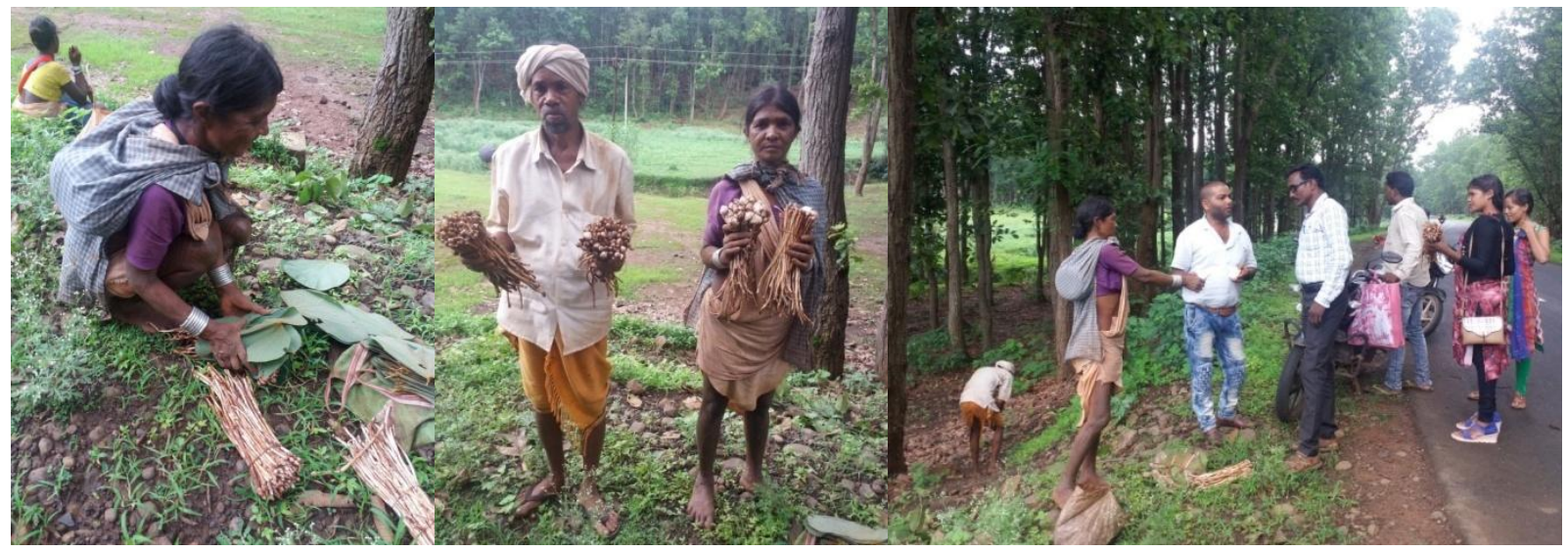

Fig.20\&21 Termitomyces: sale of mushroom at local market in Dindori, Madhya Pradesh

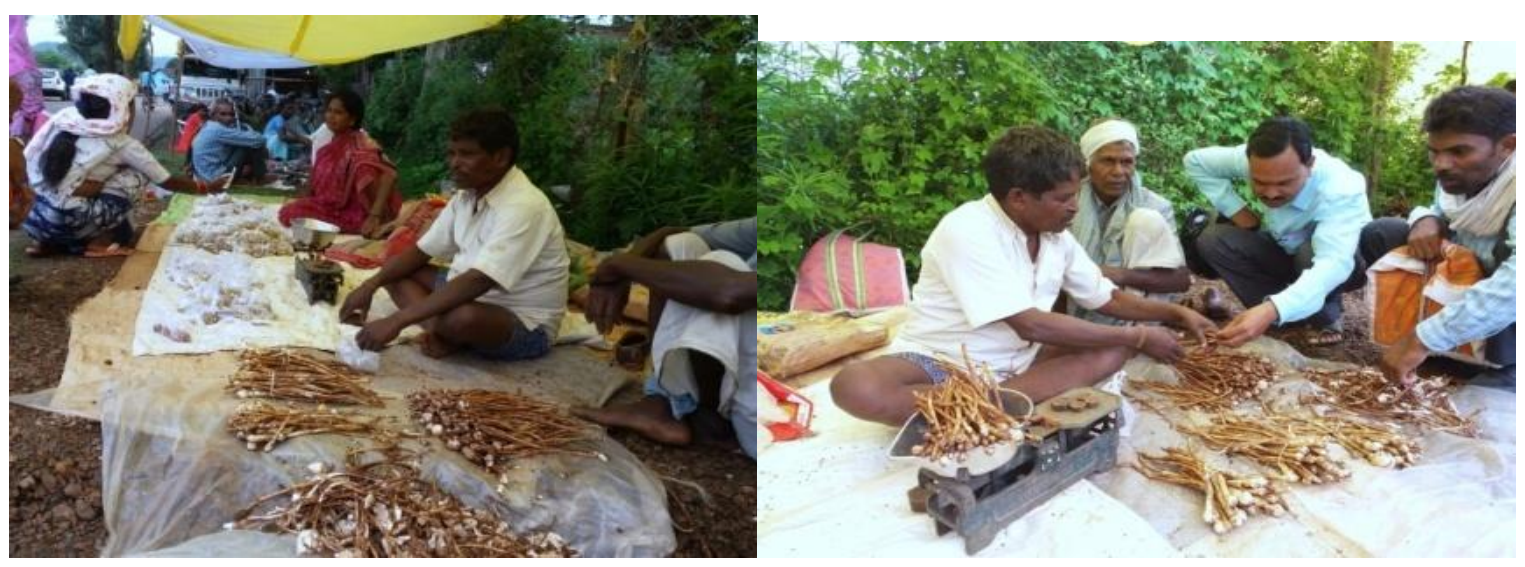


Fig.22\&23 Termitomyces: 22 sale of mushroom along with vegetable of tree origin (menhar) and 23 sale of mushroom at Bajag, Dindori, Madhya Pradesh

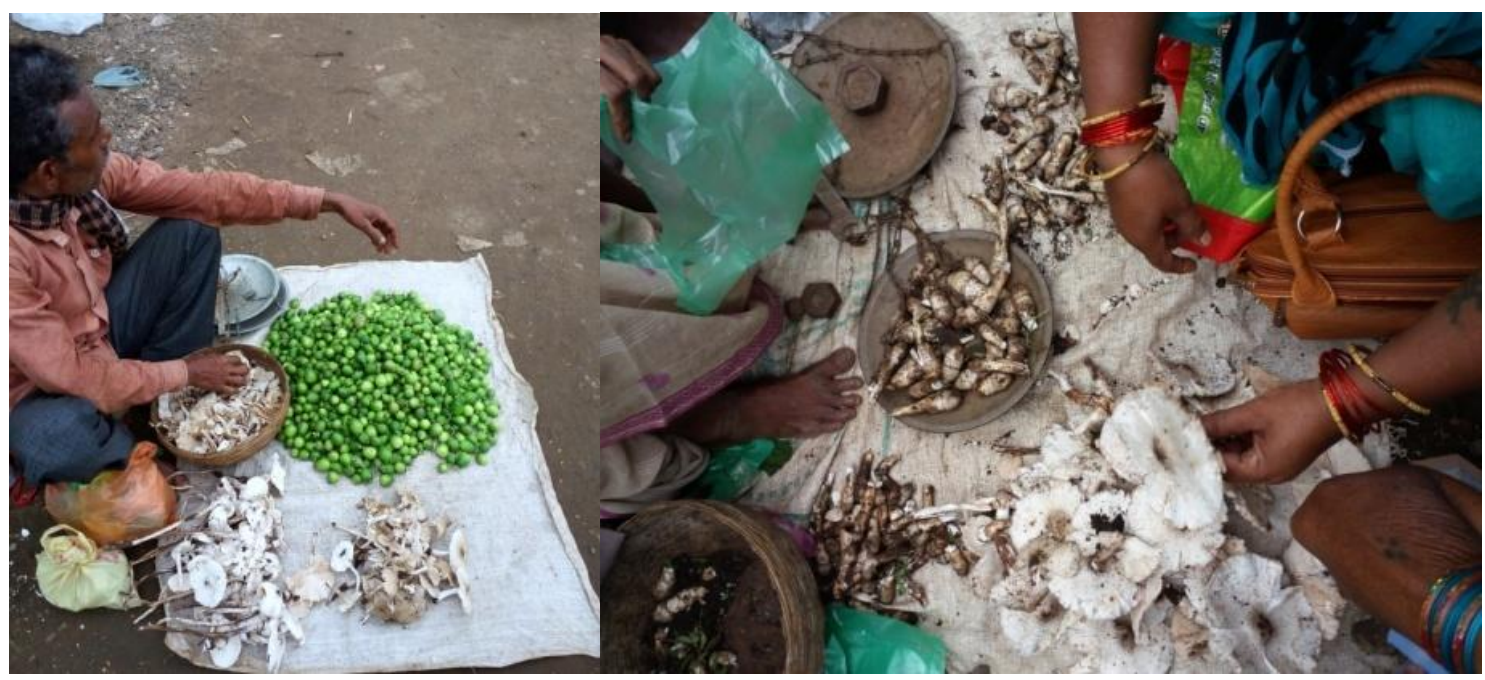

Some Amanita mushrooms were also collected from sal forest. Vrinda et al. (2005) also reported collection of edible Amanita from Western Ghats of Kerala. Recently seven edible species of Russula including: Russula crustosa, R. lutea, R. lepida, $R$. olivacea, $R$. parvovirescens, $R$. senecis and Russula virescens were listed from different parts of India (Verma et al., 2018b). R. senecis is the mushroom frequently collected by tribes in West Bengal. This mushroom was originally reported from Japan and also frequently reported growing in association with Vateria india in dipterocarp forests of Western Ghats and mixed forests of Sikkim, Himalayas (Khatua et al., 2015).

When bulk quantity of mushrooms was collected, it can be preserved under soil up to 3-4 days and desired quantity will be fetched for daily use. This indigenous method of preservation is also in practice in Eastern lateritic parts of India and the highest yield was during July (Manna et al., 2014; Manna and Roy 2014). Astraeus hygromatricus is generally collected from sal forest of central India in bulk and sold in local markets (Figs. 10-13). Another species of this genus, Astraeus odoratus mushroom which formed ecto-mycorrhiza with trees was also collected mainly from the fire affected scrub jungle of lateritic soils in Konaje, Karnataka, (Pavithra et al., 2015).

This mushroom was also associated with tree species like Shorea robusta in Rajmahal Hills and Dalabari region of Jharkhand (Hembrom et al., 2014). Burning reduces the diversity of saprophytic macro-fungi, but ectomycorrhizal mushrooms survive in subsoil along with roots it support the growth of selected macrofungi like, A. hygrometricus in northern Thailand (Sysouphanthong et al., 2010). This is one of the highly prized mushrooms costing Rupees 300-500 per kg. In Northern Thailand, yield of A. odoratus was significantly increased in burnt floors of dipterocarp-oak forests and serve as an important culinary delicacy as well as household income (Kennedy et al. 2012).

In conclusion, mushrooms belonging genera, Astraeus, Russula and Termitomyces were collected by local and tribal people from sal forest of Dindori district and sold in local markets. Thus the sal forests provide a source of income to local inhabitants in the form of wild edible mushrooms. 


\section{Acknowledgements}

The authors are thankful to Dr. G. Rajeshwar Rao, Director, Tropical Forest Research Institute, Jabalpur for providing the research facilities. The work presented was conducted under project ID No. 246/TFRI/2018/Patho1(23) funded by Indian Council of Forestry Research \& Education (ICFRE), Dehradun.

\section{References}

Ahmad S (1950). Studies in gasteromycetes. Sydowia 4: 124-129.

Berkeley MJ (1852). Decades XXXIX, XL. Sikkim and Khassya fungi. Hooker's Journal of Botany and Kew Garden Miscellany 4: 130-142.

Bhaben T, Lisha G, Sarma GC (2011). Wild edible fungal resources used by ethnic tribes of Nagaland, India. Indian Journal of Traditional Knowledge 10(3): 512515.

Christensen M, Bhattarai S, Devkota S, Larsen HO (2008). Collection and use of wild edible fungi in Nepal. Economic Botany 62(1): 12-23.

Dring DM. (1964) Gasteromycetes of West Tropical Africa. Mycological Papers 98: 1-60.

Fangfuk W, Petchang R, Toanun C, Fukuda M, Yamada A (2010). Identification of Japanese Astraeus, based on morphological and phylogenetic analyses. Mycoscience 51: 291-299.

Hall IR, Lyon AJ, Wang Y, Sinclair L (1998). Ectomycorrhizal fungi with edible fruiting bodies, Boletus edulis. Economic Botany 52: 44-56.

Harsh NSK, Tiwari CK, Rai BK (1996). Forest fungi in the aid of tribal women of Madhya Pradesh. Sustain Forest $1: 10-5$.

Harsh NSK, Joshi K (2008). Mushrooms: the vegetable of the future. India Sci Technol. www.nistads.res.in
Harsh NSK, Rai BK, Ayachi SS (1993). Forest fungi and tribal economy-a case study in Baiga tribes of MP. Journal of Tropical Forestry 9: 94-96.

Harsh NSK, Rai BK, Tiwari DP (1993) Use of Ganoderma lucidum in folk medicine. Indian Journal of Tropical Biodiversity 1(3-4): 324-326

Heim R. (1942). Nouvelles études descriptives sur les agarics termitophiles d'Afrique tropicale. Archives du Muséum National d'Histoire Naturelle (in French) 18(6): 107-66.

Karun NC, Sridhar KR (2017). Edible wild mushrooms of the Western Ghats: Data on the ethnic knowledge. Data Brief 14: $320-328$

Khatua S, Dutta AK, Acharya K. (2015). Prospecting Russula senecis: A delicacy among the tribes of West Bengal. PeerJ PrePrints 3:e707v2

Makonde HM, Boga HI, Osiemo Z, Mwirichia R, Stielow JB, Göker M, Klenk H-P (2013). Diversity of Termitomyces Associated with Fungus-Farming Termites Assessed by Cultural and Culture-Independent Methods. PLoS One 8(2): e56464. Published online 2013 Feb 20. doi: 10.1371/journal.pone.0056464

Manna S, Ray D, Roy A (2014). Tribal relation to spatio-temporal variation of wild mushrooms in eastern lateritic part of India. Ethnobotany Research \& Applications 12: 15-24.

Manna S, Roy A (2014). Economic contribution of wild edible mushrooms to a forest fringe ethnic community in some eastern lateritic parts of India. Journal of Forest Research 19(1): 5261.

Mohanan C (2011). Macrofungi of Kerala. Kerala Forest Research Institute, Hand Book \# 27, Kerala, India, 597pp.

Mohanan C (2014). Macrofungal diversity in the Western Ghats, Kerala, India: 
members of Russulaceae. Journal of Threatened Taxa 6(4): 5636-5648.

Pavithra M, Greeshma AA, Karun NC, Sridhar KR (2015). Observations on the Astraeus spp. of Southwestern India. Mycosphere 6(4): 421-432

Persoon CH (1801). Synopsis methodica fungorum. H. Dieterich, Göttingen.

Pradeep CK, Vrinda KB (2007). Some noteworthy agarics from Western Ghats of Kerala. Journal of Mycopathological Research 45(1): 1-14.

Pradeep CK, Vrinda KB (2010). Ectomyrrhizal fungal diversity in three types and their association with endemic, indigenous and exotic species in the Western Ghar forests of Thiruvanthapuram districtm Kerala. Journal of Mycopathological Research 48(2): 279-289.

Pradhan P, Banerjee S, Roy A, Acharya K (2010). Role of wild edible mushrooms in the Santal livelihood in lateritic region of West Bengal. Journal of Botanical Society of Bengal 64: 61-65.

Pradhan P, Dutta AK, Roy A, Basu SK, Acharya K (2013a) Inventory and spatial ecology of macro-fungi in the Shorea robusta forest ecosystem of lateritic region of West Bengal. Biodiversity 13: 88-99.

Pradhan P, Dutta AK, Roy A, Basu SK, Acharya K (2013b). Macrofungal diversity and habitat specificity: A case study. Biodiversity 14: 147-161.

Purkayastha RP, Chandra Andrilla (1975). Termitomyces eurhizus, a new Indian edible mushroom. Transactions of the British Mycological Society 64(1): 168170.

Rai M, Tidke G, Wasser SP (2005). Therapeutic potential of mushrooms. Nat. Prod. Radian 4(4): 246-57.

Sachan SK, Patra JK, Thatoi HN (2013). Indigenous knowledge of ethnic tribes for utilization of wild mushrooms as food and medicine in similipal biosphere reserve, Odisha, India. J Agric Technol 9(2):403-16.

Sarma TC, Sarma I, Patiri BN (2010). Wild edible mushrooms used by some ethnic tribes of western Assam. Bioscan 3: 613-25.

Semwal KC, Stephenson SL, Bhatt VK, Bhatt RP (2014). Edible mushrooms of the Northwestern Himalaya, India: a study of indigenous knowledge, distribution and diversity. Mycosphere 5(3): 440461.

Sysouphanthong P, Thongkantha S, Zhao R, Soytong K, Hyde KD (2010). Mushroom diversity in sustainable shade tea forest and the effect of fire damage. Biodiversity and Conservation 19: 1401-1415.

Verma RK, Mishra SN, Pandro Vimal, Thakur AK (2018a). Diversity and distribution of Calvatia species in India: a new record from central India. International Journal of Current Microbiology and Applied Science 7(9): 2540-2551

Verma RK, Pandro Vimal (2018a). Distribution of Boleteceous mushrooms in India, some new records from Sal forest of central India. International Journal of Current Microbiology and Applied Science 7(6): 1694-1713.

Verma RK, Pandro Vimal (2018b). Diversity and distribution of amanitaceous mushrooms in India, two new reports from sal forest of central India. Indian Journal of Tropical Biodiversity 26(1): 42-54.

Verma RK, Pandro Vimal, Pyasi Abhishek (2018b). Diversity and distribution of Russula in India with reference to central Indian species. International Journal of Current Microbiology and Applied Science 7(10): 3078-3103.

Verma RK, Rajput PS, Pandro Vimal (2017a). Diversity of Macro-fungi in central 
India-VIII: Astraeus hygrometricus, an ectomycorrhizal and neutraceutical mushroom from sal forests. Van Sangyan 4(10): 18-29.

Verma RK, Thakur AK, Pandro Vimal (2017b). Diversity of Macro-fungi in central India-X: edible mushrooms Macrocybe crassa and Macrocybe lobayensis. Van Sangyan 4(12): 39-49.

Verma RK, Asaiya AJK, Choubey Chitra, Pandro Vimal (2017c). Diversity of Macro-fungi in central India-IX: Laetiporus sulphureus. Van Sangyan 4(11): 1-6.

Verma RK, Verma P (2017a). Diversity of macro-fungi in central India -IV. Auricularia auricular-judae, a neutracetical jelly mushroom. Van Sangyan 4(2): 23-31.
Verma RK, Verma P (2017b). Diversity of macro-fungi in central India - VI. Schizophyllum commune. Van Sangyan 4(7): 15-23.

Vrinda KB, Pradeep CK (2014). Wild edible mushrooms from Kerala forests - a source of food and income (final project report submitted to department of planning and economic affairs, WGDP, Government of Kerala). Jawaharlal Nehru Tropical Botanical Garden \& Research Institute, Palode, Thiruvananthapuram. $124 \mathrm{p}+10$ colored plates.

Vrinda KB, Pradeep CK, Kumar SS (2005). Occurrence of a lesser known edible Amanita in the Western Ghats of Kerala. Mushroom Research 14(1): 5-8.

\section{How to cite this article:}

Verma, R.K., Vimal Pandro, S.N. Mishra, Diwyansh Raj and Asaiya, A.J.K. 2019. Sal Forest: A Source of Wild Edible Mushrooms for Livelihood Support to Tribal People of Dindori District, Madhya Pradesh, India. Int.J.Curr.Microbiol.App.Sci. 8(01): 563-575. doi: https://doi.org/10.20546/ijcmas.2019.801.063 